\title{
Analisis Likuiditas Laporan Keuangan Perusahaan Dagang Dalam Zahir Accounting Versi 5.1
}

\author{
M.L.Dian Ela Revita ${ }^{1}$, Indah Ariyati ${ }^{2}$ \\ ${ }^{1,2}$ Universitas Bina Sarana Informatika \\ e-mail: ${ }^{1}$ maria.dev@bsi.ac.id, ${ }^{2}$ indah.ayi@bsi.ac.id \\ Diterima Direvisi Disetujui \\ 14-02-2020 05-03-2020 10-03-2020
}

\begin{abstract}
Abstrak Pengambilan keputusan merupakan hal yang terpenting didalam pengelolaan perusahaan. Kesalahan didalam pengambilan keputusan dapat mengakibatkan kerugian, yang pada akhirnya perusahaan akan mengalami kerugian. Pencegahan kerugian adalah dengan melakukan analisis laporan keuangan sesuai dengan prinsip - prinsip akuntansi. Dengan melakukan analisis laporan keuangan diharapkan manajemen dapat menilai kondisi keuangan perusahaan, sehingga mudah memahami, sehingga keputusan keuangan yang diambil dapat sesuai dengan kelemahan dan kekuatan keuangan perusahaan tersebut. Dalam ekonomi mikro, salah satu tujuan perusahaan adalah maksimalisasi laba perusahaan. Penggunaan Program Zahir Accounting versi 5.1 dapat membantu manajemen perusahaan dagang Salsabila Mart Bekasi dalam menganalisa laporan keuangan sebagai tolak ukur pengambilan keputusan. Analisa likuiditas yang diperoleh dari perhitungan aplikasi Zahir Accounting menunjukkan bahwa Salsabila Mart Bekasi pada bulan Juni 2019 mampu menyelesaikan utang jangka pendek dari harta lancar yang dimiliki perusahaan. Dari keseluruhan aspek likuiditas yang dihitung, hal ini menunjukkan Salsabila Mart Bekasi merupakan perusahaan yang sangat likuid, dengan hasil rata-rata likuiditas Current Ratio : 36.639,41\%; Qucik Ratio : 23.351,44\% dan Cash Ratio: 22.551,44\%. Harta lancar yang dimiliki masih jauh lebih banyak dari kewajiban lancar yang harus dipenuhi selama bulan Juni. Dalam penelitian ini aplikasi Zahir Accounting Versi 5.1 dapat membantu pihak internal dan eksternal perusahaan mendapatkan laporan keuangan dan analisa laporan keuangan sebagai informasi yang dipakai dalam membuat keputusan manajerial.
\end{abstract}

Kata Kunci:Analisis Likuiditas, Laporan Keuangan, Zahir Accounting

\begin{abstract}
Abstack Decision making is the most important thing in managing a company. Errors in decision making can result in losses, which in turn the company will suffer losses. Loss prevention is to conduct an analysis of financial statements in accordance with accounting principles. By analyzing the financial statements, management is expected to be able to assess the company's financial condition, so that it is easy to understand, so that the financial decisions made can be in accordance with the company's financial weaknesses and strengths. In microeconomics, one of the goals of a company is maximizing corporate profits. The use of Zahir Accounting Program version 5.1 can help the management of the Salsabila Mart Bekasi trading company in analyzing financial statements as a benchmark for decision making. The liquidity analysis obtained from the Zahir Accounting application calculation shows that Salsabila Mart Bekasi in June 2019 was able to settle short-term debt from current assets owned by the company. From all aspects of calculated liquidity, this shows that Salsabila Mart Bekasi is a highly liquid company, with an average liquidity yield Current Ratio: 36,639.41\%; Qucik Ratio: 23,351.44\% and Cash Ratio: 22,551.44\%. Current assets are still far more than current liabilities that must be fulfilled during June. In this research the Zahir Accounting Version 5.1 application can help the company's internal and external parties obtain financial reports and analysis of financial statements as information used in making managerial decisions.
\end{abstract}

Keywords: Liquidity Analysis, Financial Statements, Zahir Accounting

\section{PENDAHULUAN}

Pengambilan Keputusan merupakan hal yang terpenting didalam pengelolaan perusahaan. Kesalahan didalam pengambilan keputusan dapat mengakibatkan kerugian, yang pada akhirnya perusahaan akan mengalami kepailitan. Hal ini menjadi hal yang harus dihindari. Pengambilan keputusan yang tepat, akan membawa perusahaan bertahan didalam persaingan dan menjadi perusahaan besar dan maju. Pengelolaan perusahaan, terutama pengelolaan keuangan perusahaan memerlukan informasi yang mudah, tepat dan cepat. Laporan keuangan menunjukkan kinerja manajemen dan kondisi keuangan perusahaan selama satu periode (Rusiyati, 2018), informasi laporan 
keuangan berupa Laporan laba rugi, neraca dan arus kas digunakan sebagai dasar untuk pengambilan keputusan yang harus dianalisis.

Kegiatan analisis laporan keuangan diharapkan dapat dihasilkan kondisi keuangan perusahaan sehingga keputusan keuangan yang akan diambil dapat sesuai dengan kelemahan dan kekuatan keuangan sebuah perusahaan. Manfaat lain yang didapat dengan melakukan analisis laporan keuangan, manajemen dapat membuat proyeksi laporan keuangan di masa yang akan datang berdasarkan rencana operasional dan strategis perusahaan, sesuai dengan tujuan perusahaan yaitu mendapatkan laba serta meningkatkan nilai perusahaan, sehingga pada akhirnya perusahaan dapat maju, dan memberikan manfaat bagi pihak internal dan eksternal perusahaan.

Dalam dunia ekonomi tujuan perusahaan adalah memaksimalkan laba dengan menekankan pada pemanfaatan barang modal secara efisien (Keown, Martin, Petty, \& Davit F.Scott, 2008). Laporan keuangan perusahaan yang sudah diperiksa oleh akuntan publik akan, lebih banyak bermanfaat langsung bagi para kreditur dan pemerintah daripada bagi manajemen maupun pemodal (pemegang saham atau pemilik), Hasil modifikasi analisis laporan keuangan diperlukan agar informasi keuangan tersebut bermanfaat dalam pengambilan keputusan manajemen maupun pemilik/pemegang saham, apakah akan terus menginvestasikan dananya atau menariknya kembali.

Dana yang dimiliki perusahaan berasal dari pemodal, mereka menginginkan imbalan atas dana tersebut, berupa bunga atau keuntungan. Bunga atau keuntungan dapat mereka terima, apabila perusahaan mendapatkan keuntungan. Tingkat keuntungan itu penting, karena merupakan sumber yang akan digunakan kembali untuk operasional perusahaan dan membayar kewajiban perusahaan. Pembuatan laporan keuangan dan analisa laporan keuangan bermanfaat bagi manajemen, investor maupun pihak lain dalam pengambilan keputusan, sehingga diperlukan ketepatan dan kecermatan dalam pembuatannya. Program Zahir Accounting versi 5.1 diharapkan akan memberikan manfaat yang tepat bagi pihak-pihak internal maupun eksternal perusahaan untuk mendapatkan informasi yang tepat, cepat, dan akurat (Syifaunnisa \& Faizah, 2018), informasi tersebut dapat membantu didalam pengambilan keputusan yang bermanfaat bagi kelangsungan dan kemajuan perusahaan. (Tyas, Revita, \& Ariyati, 2019)

\section{Analisis Rasio Likuiditas}

Angka Rasio Keuangan merupakan "penulisan ulang data akuntansi ke dalam bentuk perbandingan dalam rangka mengidentifikai kekuatan dan kelemahan keuangan perusahaan" (Keown et al., 2008). "Analisis Ratio merupakan cara Analisa dengan menggunakan perhitungan perbandingan dari data kuantitatif yang terdapat dalam neraca maupun laba rugi"(Hartono, 2018).

Analisa ratio merupakan salah satu metode yang banyak digunakan untuk melakukan interprestasi/analisis laporan keuangan. "Analisa ratio digunakan dengan membandingkan suatu angka tertentupada suatu akun terhadap angka dari akun lainnya" (Murhadi, 2015), dengan melakukan analisis ratio dapat menjelaskan hubungan antara dua atau lebih data keuangan, dari akun harta, utang dan modal maupun pendapatan dan biaya perusahaan. Data keuangan yang dipergunakan akan disesuaikan dengan kebutuhan perusahaan

Secara umum, menurut (Kasmir, 2014) ratio keuangan dibagi menjadi 4 (empat) yaitu :

a. Ratio Profitabilitas (Profitability Ratio)

Ratio profitabilitas digunakan untuk mengukur kemampuan perusahaan dalam menghasilkan keuntungan untuk perusahaan. Rasio profitabilitas dianggap memiliki peranan yang krusial bagi kelangsungan perusahaan karena "urat nadi" suatu perusahaan akan bergantung dari sejauh mana perusahaan bisa mendapatkan keuntungan.

b. Ratio Likuiditas (Liquidity Ratio)

Ratio likuiditas digunakan untuk mengukur kemampuan perusahaan dalam membayar atau melunasi utang atau kewajiban dalam skala jangka pendek yang harus segera dipenuhi.

c. Ratio Solvabilitas (Solvency Ratio)

Ratio solvabilitas digunakan untuk mengukur kemampuan perusahaan dalam melunasi semua kewajibannya, baik kewajiban jangka panjang maupun jangka pendek, utamanya apabila disaat perusahaan yang bersangkutan harus dilikuidasi.

d. Ratio Aktivitas (Activity Ratio)

Rasio aktivitas digunakan untuk mengukur keefektifan atau efisiensi perusahaan dalam menggunakan aktiva - aktiva yang dimilikinya.

Rasio Likuiditas merupakan rasio yang digunakan perusahaan untuk mengukur kemampuannya untuk memenuhi kewajiban jangka pendek (Husnan, 2019). Berikut ini beberapa analisa dalam mengukur ratio likuiditas, yaitu :

a. Rasio Lancar (Current Ratio) merupakan Rasio yang digunakan untuk mengukur kemampuan perusahaan memenuhi kewajiban lancarnya dengan menggunakan aktiva lancar yang dimiliki perusahaan. Sebagai gambaran, apabila perbandingannya adalah 1:2 dimana artinya Current Ration-nya adalah $200 \%$, berarti aktiva lancarnya memiliki jumlah yang lebih banyak atau 2 kali dibandingkan kewajiban lancarnya. Nilai Rasio lancar lebih besar dari $100 \%$ artinya perusahaan likuid.

Rumus yang digunakan dalam menghitung rasio lancar sebagai berikut :

Current Ratio $=\frac{\text { Aktiva Lancar }}{\text { Hutang Lancar }} \times 100 \% \ldots$ (1) 
b. Rasio Cepat (Quick Ratio) merupakan rasio untuk mengukur kemampuan perusahaan memenuhi atau membayar kewajiban lancar dengan menggunakan aktiva lancar tanpa nilai persediaan yang dimiliki perusahaan. Nilai Rasio cepat lebih besar dari $100 \%$ artinya perusahaan likuid.

Rumus yang digunakan dalam menghitung rasio cepat sebagai berikut :

Quick Ratio $=\frac{\text { Aktiva Lancar }- \text { Persediaan }}{\text { Hutang Lancar }} \times 100 \%$
$\ldots$... (2)

c. Rasio Kas (Cash Ratio) merupakan rasio untuk membandingkan antara kas dan aktiva lancar setara kas yang dimiliki perusahaan dengan kewajiban lancar. Yang dimaksud dengan aktiva lancar setara kas adalah aktiva yang dapat dengan mudah dan segera diuangkan, dalam hal ini yang dimaksud adalah bank. Nilai Rasio Kas lebih besar dari $100 \%$ artinya perusahaan likuid. Rumus yang digunakan dalam menghitung rasio kas sebagai berikut :

Cash Ratio $=\frac{\text { Kas }+ \text { Aktiva setara kas }}{\text { Hutang Lancar }} \times 100 \% \quad \ldots \ldots$

\section{Laporan Keuangan}

Laporan keuangan adalah alat yang sangat penting untuk memperoleh informasi sehubungan dengan posisi keuangan (Neraca : harta, utang dan modal) dan hasil usaha (Laba/Rugi) yang telah dicapai oleh perusahaan yang bersangkutan, dengan begitu laporan keuangan diharapkan akan membantu para pengguna (user) untuk membuat keputusan ekonomi yang bersifat financial. (Hidayat, 2018). "Laporan keuangan dapat dengan jelas memperlihatkan gambaran kondisi keuangan dari perusahaan.” (Desmahary \& Kuswara, 2016). "Laporan keuangan merupakan suatu informasi yang menggambarakan kondisi keuangan suatu perusahaan, dimana informasi tersebut dapat dijadikan sebagai gambaran kinerja keuangan suatu perusahaan" (Utami \& Hidayat, 2019).

Tujuan umum laporan keuangan menurut (Sadeli \& Lili, 2014) antara lain :

a. Menyajikan informasi yang dapat diandalkan tentang kekayaan, kewajiban.

b. Menyajikan informasi yang dapat diandalkan tentang perubahan kekayaan bersih perusahaan sebagai hasil dari kegiatan usaha.

c. Menyajikan informasi yang dapat diandalkan tentang perubahan kekayaan bersih yang bukan berasal dari kegiatan usaha.

d. Menyajikan informasi yang dapat membantu para pemakai yang dapat menaksir kemampuan perusahaan memperoleh laba. e. Menyajikan informasi lain yang sesuai/relevan dengan keperluan para pemakainya.

\section{Zahir Accounting Versi 5.1}

Zahir accounting merupakan software sederhana dalam pengolahan data akuntansi yang mudah dipelajari karena kegiatan usaha sesuai bidang usaha di Indonesia. Tampilan aplikasi sangat menarik dari mulai interface program maupun dalam penyajian laporan keuangan. Software Zahir Accounting dirancang untuk dapat membantu manajemen dalam pengambilan keputusan bisnis yang disajikan dalam grafik analisa bisnis. Software Zahir Accounting merupakan software akuntansi yang dibuat secara terpadu (integrated software). (Yuswanto \& Hanafi, 2013)

Informasi perusahaan dan beberapa fasilitas Zahir Accounting dibagi berdasarkan modul-modul kebutuhan perusahaan, dapat dilihat pada gambar 1 . Melalui Zahir Accounting dapat melakukan posting jurnal umum, buku besar, neraca, laba rugi dan analisa keuangan perusahaan yang disajikan secara otomatis.

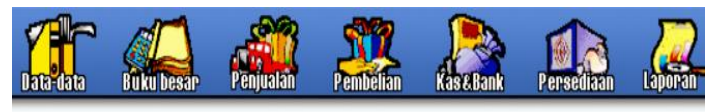

Data Master
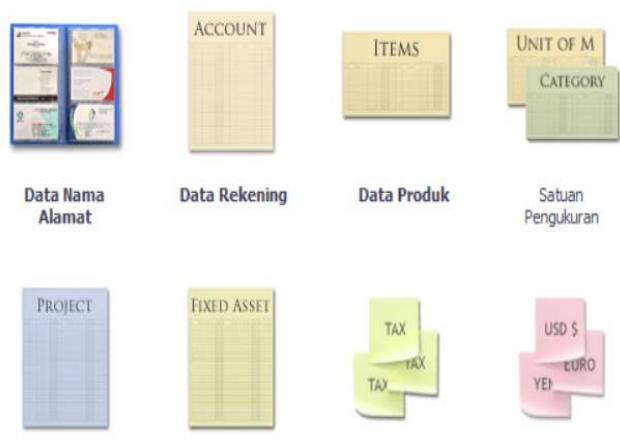

Data Proyek

Data Harta Tetap

Data Pajak

Data Mata Uang

Sumber: Data Sekunder (2019)

Gambar 1. Fasilitas Zahir Accounting Versi 5.1.

\section{METODOLOGI PENELITIAN}

Perusahaan Dagang Salsabila Mart Bekasi berdiri sejak November 2017 yang beralamat di Jl. Raya Kp. Irian RT.006/RW.026 Teluk Pucung Bekasi Utara didirikan oleh Bapak M.Abdullah yang sudah mempunyai surat izin usaha perdagangan dengan nomor 7293/895B/699.292/2017. Perusahaan ini bergerak di bidang perdagangan bahan baku kebab, dengan harapan kedepannya menjadi perusahaan besar dan menjadi pemasok serta produsen bagi perusahan perusahaan kecil lainnya yang sedang berkembang. 
Metode penelitian yang digunakan penulis dalam penelitian ini sebagai berikut :

1. Metode Observasi (Observation Method)

Penulis melakukan pengamatan dengan melihat secara langsung kegiatan yang terjadi pada Salsabila Mart Bekasi sehingga dapat diketahui prosedur sistem berjalan sampai laporan keuangan pada perusahaan tersebut.

2. Metode Wawancara (Interview)

Pengumpulan data secara lengkap dan detail dengan cara melakukan proses tanya jawab mengenai semua kegiatan di Salsabila Mart Bekasi

3. Metode Studi Pustaka (Library Method)

Penulis melakukan pengumpulan dengan membaca literatur-literatur, sumber tertulis dan buku-buku yang berhubungan dengan analisa laporan keuangan.

Penulis melakukan pengumpulan data dari transaksi data keuangan yang terjadi pada Salsabila Mart selama 1 bulan yaitu transaksi selama bulan Juni 2019. Data tersebut akan diinput pada program zahir accounting versi 5.1 sehingga menghasilkan laporan keuangan dan analisis laporan keuangan berupa grafik analisis ratio likuiditas. Hasil analisa bisnis dalam Zahir Accounting yang ditampilkan dalam grafik rasio likuiditas dijadikan acuan untuk mengetahui sampai seberapa kemampuan perusahaan dalam melunasi kewajiban jangka pendeknya. Aspek likuiditas yang dapat ditampilakn berupa current ratio, qucik ratio dan cash ratio, working Capital to Total Asset,dan perputaran piutang

\section{HASIL DAN PEMBAHASAN}

Berdasarkan kegiatan transaksi keuangan Salsabila Mart periode tanggal 1 Juni - 30 Juni 2019 yang telah diinput dalam software Zahir Accounting, maka secara otomatis Zahir Accounting akan menampilkan laporan-laporan keuangan dan analisis likuiditas yang dengan mudah dilihat oleh user. Laporan keuangan tersebut diantaranya :

\section{Laporan Laba Rugi}

Laporan keuangan suatu perusahaan yang dihasilkan pada suatu periode akuntansi yang menjabarkan unsur-unsur penjualan, harga pokok penjualan dan beban perusahaan sehingga menghasilkan suatu laba atau rugi bersih. Laporan Laba Rugi dapat dilihat pada gambar 2.

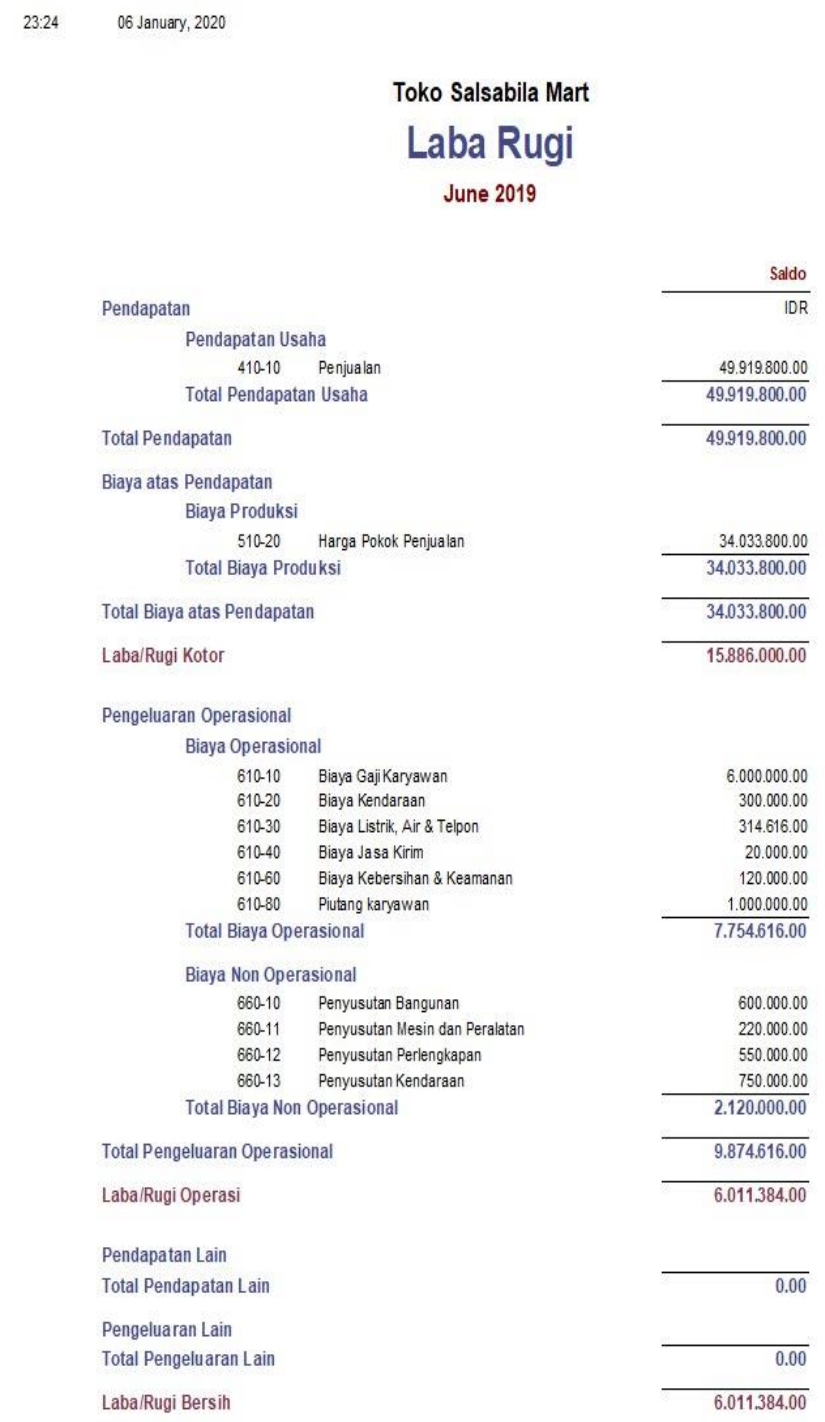

Sumber: Data Primer (2019)

Gambar 2. Laporan Laba Rugi

\section{Laporan Neraca dan perubahan modal}

Neraca merupakan Laporan posisi keuangan perusahaan, pada satu periode akuntansi. Neraca terdiri dari tiga unsur yaitu : harta, utang dan modal perusahaan. Laporan Perubahan modal, menampilkan posisi modal akhir perusahaan pada periode akuntansi. yang meliputi modal awal ditambah atau dikurangi laba/rugi kemudian dikurangi prive akan menghasikan modal akhir. Nilai modal akhir ini yang akan ditampilkan pada laporan neraca.

Laporan neraca dapat dilihat pada gambar 3, sedangkan laporan perubahan modal dapat dilihat pada gambar 4 
07:35 $\quad 07$ January, 2020

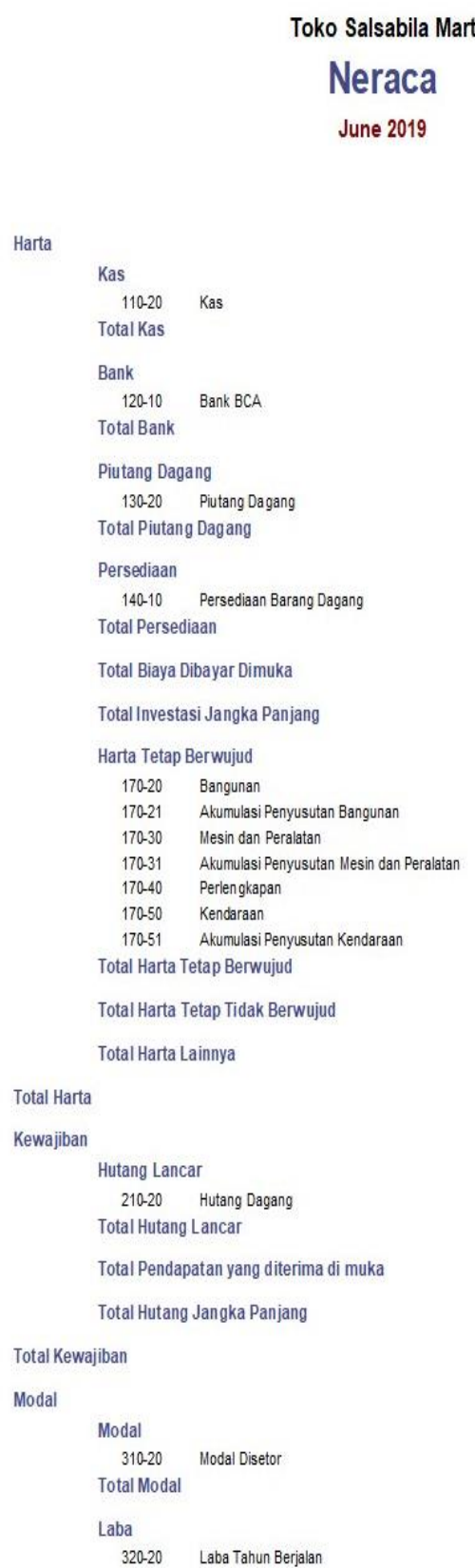

Sumber: Data Primer (2019)

Gambar 3. Laporan Neraca Standar

07:35 $\quad 07$ January, 2020

Modal

\section{Laba}

Total Laba

Total Modal

Total Kewajiban dan Modal

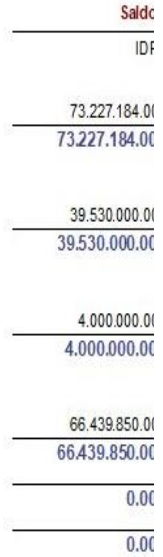

125.000 .000 .01

$-10.350 .000 .01$

15.000 .000 .01

$-3.080 .000 .01$

5.058 .000 .01

38.000 .000 .01

$\frac{-8.550 .000 .01}{161.078 .000 .06}$

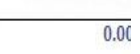

0.00

344.275 .034 .00

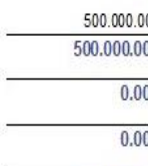

$500.000 .0 C$

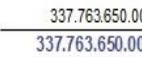

6.011 .384 .01

\section{Ratio Likuiditas}

1) Curent Rasio yang menyatakan perbandingan antara aktiva lancar dengan hutang lancar. Current Rasio sebesar : 36.639,41 \% mempunyai arti bahwa setiap $\mathrm{Rp} 1,00$ hutang lancar dijamin oleh Rp. 36.639,41. aktiva lancarnya. Current rasio dapat dilihat pada gambar 5

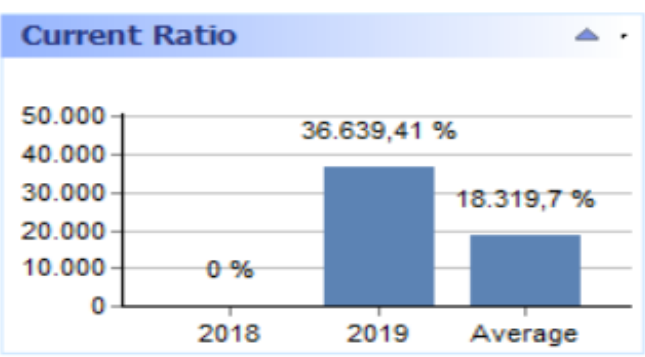

Sumber: Data Primer (2019)

Gambar 5. Current Ratio

2) Cash Ratio yang merupakan Perbandingan antara jumlah kas dan efek terhadap hutang lancar menyatakan kemampuan sesungguhnya dalam memenuhi hutang jangka pendek tepat waktu. Sebesar : 22,551,44\% mempunyai arti bahwa setiap Rp 1,00 hutang lancar dijamin oleh $\mathrm{Rp}$ 22.551,44. kas dan Bank yang dimiliki perusahaan. Cash rasio dapat dilihat pada gambar 6

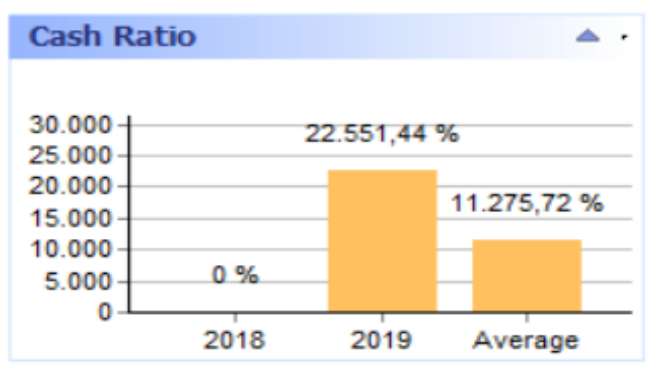

Sumber: Data Primer (2019)

\section{Gambar 6. Cash Ratio}

3) Quick Ratio merupakan perbandingan antara jumlah aktiva lancar (selain persediaan) dengan hutang lancer pada bulan Juni sebesar 23.351,44 \%. Ini berarti setiap Rp 1 hutang lancar dijamin oleh $\mathrm{Rp} 23.351,44$. aktiva lancar (tanpa persediaan) perusahaan. Quick rasio dapat dilihat pada gambar 7

Sumber: Data Primer (2019)

Gambar 4. Laporan Perubahan Modal 


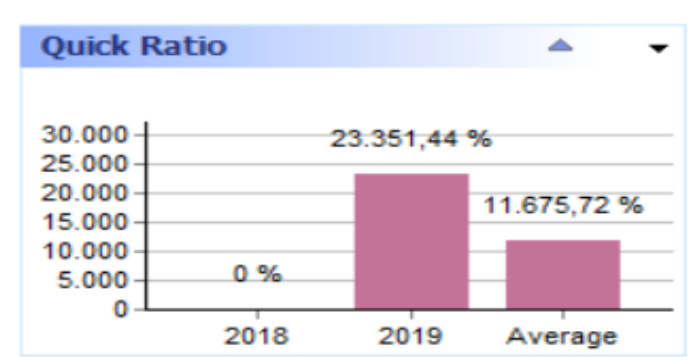

Sumber: Data Primer (2019)

\section{Gambar 7. Quick Ratio}

4) Working Capital to Total Asset, Merupakan perbandingan antara harta lancar dikurangi hutang lancar terhadap total asset (harta yang dimiliki). Working Capital to Total Asset pada bulan Juni 2019 memperoleh 53,07\%, ini berarti Modal kerja yang dimiliki perusahaan untuk melakukan operasional perusahaan 53,07 \% dari total Asset yang dimiliki perusahaan. Hal ini menunjukkan perusahaan dapat membiayai modal sendiri yang dibutuhkan dari modal keseluruhan yang dimiliki. Working Capital to Total Asset dapat dilihat pada gambar 8

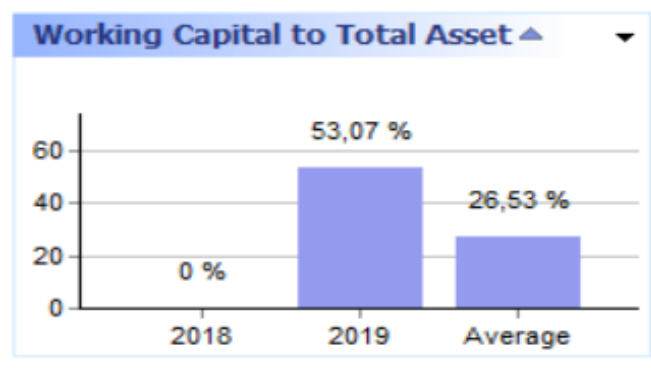

Sumber: Data Primer (2019)

Gambar 8. Working Capital to Total Asset

5) Perputaran Piutang, merupakan perbandingan antara total penjualan dengan rata-rata piutang dalam satu tahun. Menunjukkan bahwa penagihan piutang kira-kira 24,96 kali dapat dilakukan dalam setahun, ini berarti periode rata-rata yang diperlukan untuk mengumpulkan piutang adalah 14.34 hari.

Rata - rata Pengumpulan $=\frac{\text { Jumlah Hari }}{\text { Perputaran Piutang }}$

Perputaran Piutang dapat dilihat pada gambar. 9

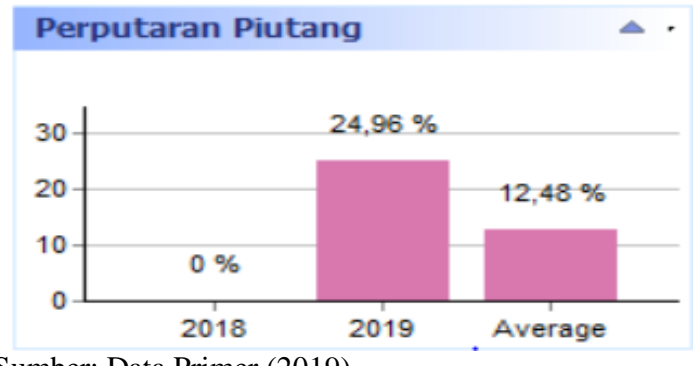

Sumber: Data Primer (2019)

Gambar 9. Perputaran Piutang

\section{KESIMPULAN}

Penggunaan Program Zahir Accounting versi 5.1 dapat membantu Manajemen Salsabila Mart untuk mendapatkan informasi dengan mudah, cepat, dan akurat berupa Laporan Keuangan dan Analisa Laporan Keuangan yang bermanfaat didalam pengambilan Keputusan.

Analisa Likuiditas yang diperoleh dari perhitungan program zahir Accounting menunjukkan Salsabila mart pada bulan Juni 2019 mampu memenuhi kewajiban jangka pendek dari harta lancar yang dimiliki perusahaan. Dari keseluruhan Aspek likuiditas yang dihitung. Hal ini menunjukkan Salsabila Mart Bekasi merupakan perusahaan yang sangat likuid. Artinya perusahaan sangat mampu memenuhi kewajiban jangka pendek dari Harta lancar yang dimiliki. Harta lancar yang dimiliki masih jauh lebih banyak dari kewajiban lancar yang harus dipenuhi selama bulan Juni. Pembuatan Laporan akan memberikan gambaran analisa yang baik, apabila laporan yang dibuat selama periode 1 tahun, atau minimal 3 - 6 bulan. Hal ini dapat memberikan informasi kepada manajemen, bahwa perusahaan bisa memanfaatkan dana lancarnya untuk mengembangkan perusahaan, misalnya dengan mengajukan tambahan dana dari investor atau dari lembaga perbankan, demi meningkatkan perusahaan. Penulis menyarankan untuk melakukan penelitian yang sama dengan menggunakan data transaksi 3 - 6 bulan agar analisa likuiditas yang dihasilkan dapat menggambarkan keadaan keuangan perusahaan selama periode tertentu yang sebenarnya. Angka tersebut dapat digunakan untuk mengantisipasi keadaan keuangan perusahaan yang langsung mempengaruhi keuntungan perusahaan pada akhir periode. Salah satu manfaat yang dihasilkan dari analisa likuiditas perusahaan mengetahui lebih cepat apakah harta lancar yang dimiliki sudah dimanfaatkan secara efisien ataukah tidak, dalam arti dana yang dimiliki tidak dimanfaatkan secara efisien. Penggunaan dana secara efisien akan dapat menghasilkan keuntungan yang terbaik bagi perusahaan. Dalam penelitian ini program Zahir accounting versi 5.1 akan membantu pihak internal maupun eksternal perusahaan mendapatkan Laporan Keuangan dan analisa laporan keuangan dengan mudah, cepat dan akurat sebagai 
informasi yang digunakan untuk membuat keputusan manajerial.

\section{REFERENSI}

Desmahary, Y., \& Kuswara, H. (2016). Aplikasi Akuntansi Zahir Accounting Untuk Pengolahan Data KeuanganPada PD. Nugraha Jakarta. Jurnal Online Insan Akuntan, I(2), 391-412.

Hartono. (2018). Konsep Analisa Laporan Keuangan dengan Pendekatan Rasio dan SPSS (Pertama). Yogyakarta: Deepublish.

Hidayat, D. W. W. (2018). DASAR-DASAR ANALISA LAPORAN KEUANGAN. (F. Fabri, Ed.) (I). Sidoharjo: Uwais Inspirasi Indonesia.

Husnan, S. (2019). Manajemen Keuangan (Edisi Keti). Tangerang: Universitas Terbuka.

Kasmir. (2014). Analisis Laporan Keuangan. Jakarta: Rajawali Pers.

Keown, A. J., Martin, J. D., Petty, J. W., \& Davit F.Scott, J. (2008). Manajemen Keuangan: Prinsip dan Penerapan (Edisi 10). University of Central Florida: Indeks.

Murhadi, W. ra. (2015). Analisis Laporan Keuangan, Proyeksi dan Valuasi Saham. Jakarta: Salemba.
Rusiyati, S. (2018). Analisis Pengaruh Rasio Keuangan Terhadap Pertumbuhan Laba Pada Bank Persero di Indonesia. Cakrawala, XVIII, 37-42.

Sadeli, \& Lili, M. (2014). Dasar-Dasar Akuntansi. Jakarta: Bumi Aksara.

Syifaunnisa, U., \& Faizah, S. (2018). Transaksi Data Keuangan PD. Mekar Wangi Abadi Menggunakan Zahir Accounting Versi 5.1. BINA INSANI ICT JOURNAL, 5, 113-122.

Tyas, A. I., Revita, M. L. D. E., \& Ariyati, I. (2019). Sistem Informasi Pengolahan Data Akuntansi Perusahaan Menggunakan Zahir Accounting Versi 5.1. Fundamental Management Journal FUNDAMENTAL MANAGEMENT JOURNAL ISSN: EISSN : 2540-9220, 4(1), 54.

Utami \& Hidayat. (2019). SISTEM INFORMASI PENGOLAHAN DATA AKUNTANSI PERUSAHAAN MENGGUNAKAN ZAHIR ACCOUNTING VERSI 5.1. Fundamental Management Journal FUNDAMENTAL MANAGEMENT JOURNAL ISSN: EISSN : 2540-9220, 4(1), 54.

Yuswanto, \& Hanafi, L. (2013). Komputerisasi Akuntansi Dengan Zahir. Jakarta: PT. Prestasi Pustakaraya. 